\title{
Effect of salt stress on the growth of Lippia gracilis Schauer and on the quality of its essential oil
} Roberto Carlos Grillo Ragagnin ${ }^{1}$, Cynthia Cavalcanti Albuquerque ${ }^{1,3}$, Francisco Fábio Mesquita Oliveira ${ }^{1}$, Ricardo Gonçalves
Santos ${ }^{1}$, Eleneide Pinto Gurgel ${ }^{1}$, Jaécio Carlos Diniz ${ }^{2}$, Simone Alves Serafim Rocha ${ }^{2}$ and Francisco Arnaldo Viana ${ }^{2}$

Received: 19 September, 2013. Accepted: 27 January, 2014

\begin{abstract}
This study evaluated the effect of salt stress on the growth of Lippia gracilis Schauer, a species native to the caatinga (shrublands) of Brazil and rich in essential oils, as well as on the quality of its oil. We exposed individuals of L. gracilis to $\mathrm{NaCl}$, in the following concentrations, for a period of 40 days: $25 \mathrm{mM} ; 50 \mathrm{mM} ; 5 \mathrm{mM}$; and $100 \mathrm{mM}$. An additional group of plants was not exposed to $\mathrm{NaCl}$ (controls). Data were collected on days 20 and 40 . We evaluated relative growth rate; shoot and root dry weight; relative water content; proline concentration in leaves; and chemical composition of the essential oil. At all concentrations, $\mathrm{NaCl}$ reduced the relative growth rate in comparison with that observed for the controls. No significant difference in relative water content was observed among treatments. In all treatments, the proline concentration in leaves was highest on day 40. Salt stress did not affect the yield or the concentrations of the constituents of the essential oil of L. gracilis, carvacrol and thymol showing the highest concentrations in all treatments.
\end{abstract}

Key words: Alecrim-da-chapada, carvacrol, salt stress, thymol

\section{Introduction}

The productive potential and yield of some plant species are strongly affected by the environment. The presence of salts in the soil and in irrigation water is an important environmental factor because it can directly influence growth and crop production, particularly under certain weather conditions (Stanev 2010; Baser \& Buchbauer 2010). Increasing salinization, which is a growing phenomenon worldwide, especially in arid and semi-arid regions, is caused by climatic conditions and agricultural irrigation (Sairam \& Tyagi 2004). The unregulated use of fertilizers results in the contamination of irrigation water, which contributes to increasing salt concentrations in certain areas. Salinization and soil saturation problems have been identified in approximately $50 \%$ of the 250 million irrigated hectares worldwide; 10 million hectares are abandoned annually as the result of such problems (Lima-Júnior \& Silva 2010).

The immediate effects that salinization has on plants are decreased osmotic potential, nutritional imbalance due to high ionic concentration, and the toxic effects of certain ions, especially chlorine and sodium (Munns 2002; Flowers 2004; Willadino \& Camara 2010). Soil salinization results in reduced biomass accumulation, because of the metabolic cost of energy associated with adapting to salt stress conditions. The increase in osmotic pressure of the soil solution and the reduction in the water infiltration rate result in water limitation for plants (Taiz \& Zeiger 2009).

Water limitation has a negative effect on the growth and development of most plant species. However, water stress and other abiotic stresses have often been shown to have positive effects in medicinal and aromatic plants by influencing the accumulation of active constituents (Gobbo-Neto \& Lopes 2007). This becomes relevant when the cultivation of resistant species and production of metabolites of economic importance in semi-arid regions where plants are subjected to abiotic stress are considered in conjunction. In herbaceous plants and shrubs, for instance, the concentrations of terpene compounds are likely to increase in plants grown under stress conditions, especially water stress-even moderate water stress (Lima et al. 2003; Gobbo-Neto \& Lopes 2007; Taarit et al. 2010).

Essential oils are among the chemical compounds of economic importance produced by some plant species. These volatile compounds, which are produced and stored in trichomes, are involved in plant-animal, plantmicroorganism, and plant-plant interactions that aid plant

\footnotetext{
${ }^{1}$ Departamento de Ciências Biológicas da Faculdade de Ciências Exatas e Naturais, Campus Central da Universidade do Estado do Rio Grande do Norte, Rua Professor Antonio Campos, S/N Presidente Costa e Silva CEP 59625-620 Mossoró, RN, Brasil

${ }^{2}$ Departamento de Química da Faculdade de Ciências Exatas e Naturais, Campus Central da Universidade do Estado do Rio Grande do Norte, Rua Professor Antonio Campos, S/N Presidente Costa e Silva CEP 59625-620 Mossoró, RN, Brasil

${ }^{3}$ Author for correspondence: cycavalcanti@gmail.com
} 
maintenance, survival, and adaptation to environmental conditions (Castro et al. 2008). According to Morais (2009), essential oils from medicinal plant species occurring in the caatinga (shrublands) of Brazil are promising sources of new antimicrobials, because the climate of the caatinga promotes biosynthesis.

In northeastern Brazil, species in the genus Lippia (Verbenaceae) are widely used in folk medicine. One of the most widely used species is Lippia gracilis Schauer, known locally as Alecrim-da-Chapada, which is a native to the caatinga. The species produces an essential oil containing phytochemicals of proven antimicrobial effectiveness, in varying proportions (Albuquerque et al. 2006; Oliveira et al. 2008; Motta-Neto et al. 2010).

The ability to grow native medicinal plants adapted to conditions of high concentrations of salts in the soil while maintaining production of their active metabolites would provide small local producers the opportunity to grow lowcost crops. Few studies have evaluated the effect of salt stress on plants with medicinal potential, especially with respect to the production of secondary metabolites. This study evaluated the effect of salt stress on the growth, yield, and quality of essential oils of Lippia gracilis.

\section{Material and methods}

The study was conducted in a greenhouse at the State University of Rio Grande do Norte, in the city of Mossoró $\left(06^{\circ} 12^{\prime} 43^{\prime \prime} \mathrm{S} ; 37^{\circ} 20^{\prime} 39^{\prime \prime} \mathrm{W}\right)$. The city is located in northeastern Brazil, in the semi-arid region of the country, and has an annual average temperature of $27.5^{\circ} \mathrm{C}$, an annual average relative humidity of $68.9 \%$, an annual average cloud cover of 4.4 tenths, and an annual average rainfall of $673.9 \mathrm{~mm}$. According to the Köppen climate classification system, the climate of the region is type BSh (hot, dry steppe), summer being the rainy season (Carmo-Filho et al. 1987).

Lippia gracilis plants were collected in the municipality of Felipe Guerra, also in the state of Rio Grande do Norte, and planted in 8-L pots containing a substrate composed of washed sand, clay, and a commercial compound (Polifértil Home; Polifértil Nutrição, Importação e Exportação Ltda., Uberaba, Brazil), at 1:1:1. The water retention capacity of the substrate was evaluated before the cuttings were planted. Plants were cultivated for approximately 60 days to obtain individuals of comparable sizes. Size-selected plants were exposed to no salt stress (controls) or to one of four levels of salt stress resulting from the addition of $25,50,75$, or $100 \mathrm{mM}$ of $\mathrm{NaCl}$ (corresponding to $0.49,2.97,5.73,7.79$, and $8.49 \mathrm{mS}$ $\mathrm{cm}^{-1}$ of electrical conductivity, respectively) to the irrigation water. The experiment lasted 40 days, during which time we evaluated shoot and root dry weight; relative growth rate (RGR); relative water content (RWC); proline concentration; and the chemical composition and yield of the essential oil.

We evaluated growth by determining the dry weight of shoots and roots after 20 and 40 days of exposure to salt stress. The plant material was dried in a forced-air kiln at $70^{\circ} \mathrm{C}$. The RGR (expressed in $\mathrm{g} \cdot \mathrm{g}^{-1}$. day ${ }^{-1}$ ) reflects the temporal increase in dry weight and was calculated by the following equation:

$$
R G R=\frac{\log W_{2}-\log W_{1}}{d_{2}-d_{1}}
$$

where $W_{2}$ and $W_{1}$ are the dry weights at 40 days of exposure $\left(d_{2}\right)$ and 20 days of exposure $\left(d_{1}\right)$, respectively.

The RWC was evaluated in three leaf discs of known diameter, taken with a hole punch from the fourth leaf below the shoot apex. The discs were immediately weighed to determine the fresh weight, after which they were placed in Petri dishes over water-soaked filter paper in a biological oxygen demand incubator (at $25^{\circ} \mathrm{C}$ and $80 \%$ relative humidity) for $10 \mathrm{~h}$ in the dark. Subsequently, the discs were weighed to determine the turgid weight and dried in a forced-air kiln at $70^{\circ} \mathrm{C}$. The RWC (expressed as a percentage) was quantified by the following formula:

$$
R W C=\frac{W f-W d}{W t-W d} \cdot 100
$$

where $W f$, $W d$, and $W t$ are the fresh, dry, and turgid weights, respectively. The RWC was analyzed at 20 and 40 days of exposure.

Proline concentration was determined in expanded leaves harvested between 5:00 a.m. and 6:00 a.m. Fresh leaves $(750 \mathrm{mg})$ were crushed and placed in a test tube containing $15 \mathrm{ml}$ of 5-sulfosalicylic acid and centrifuged at $2000 \mathrm{rpm}$ for $3 \mathrm{~min}$. A mixture of $3 \mathrm{ml}$ of supernatant, $3 \mathrm{ml}$ of acetic acid, and $3 \mathrm{ml}$ of ninhydrin was heated in a water bath at $100^{\circ} \mathrm{C}$ for $1 \mathrm{~h}$. After color development, samples were cooled in an ice bath and $6 \mathrm{ml}$ of toluene was added for phase separation. The colorless fraction was discarded, and the color fraction was read at $520 \mathrm{~nm}$. Absorbance values were logged in the proline standard curve equation (Silva et al. 2010); results were expressed in $\mathrm{mM}$ of proline/g of fresh weight. This variable was assessed at 20 and 40 days of exposure.

Essential oil constituents were analyzed in fresh leaves. Data were collected in April 2012, between 5:00 a.m. and 6:00 a.m., on a $27^{\circ} \mathrm{C}$ day without rainfall. Essential oils were extracted through steam distillation using a modified Clevenger apparatus. For each treatment, we collected leaves from three plants ( $1 \mathrm{~kg}$ per plant). The leaves were weighed and placed in a 2 -L round-bottom flask containing $1.5 \mathrm{~L}$ of distilled water. The extraction process was performed over a 2 -h period at $\approx 100^{\circ} \mathrm{C}$. The yield (mass of the essential oil extracted) is expressed as a percentage of the wet mass of plant material $(\mathrm{w} / \mathrm{w})$.

The analysis and quantification of the most prevalent essential oil constituents (thymol, carvacrol, and $p$-cymene) followed the methods reported by Hajimehdipoor et al. (2010), with modifications. We used high-performance liquid 
Roberto Carlos Grillo Ragagnin, Cynthia Cavalcanti Albuquerque, Francisco Fábio Mesquita Oliveira, Ricardo Gonçalves Santos, Eleneide Pinto Gurgel, Jaécio Carlos Diniz, Simone Alves Serafim Rocha and Francisco Arnaldo Viana

chromatography (HPLC) in a Shimadzu system (Class-VP; Shimadzu, Kyoto, Japan). The system consists of three pumps (LC-10ATvp; Shimadzu), a photodiode array detector of ultraviolet spectra (SPD-M10Avp; Shimadzu), a column oven (CTO-10ASvp; Shimadzu), an autosampler (SIL-10AF; Shimadzu), an automatic collector (FRC-10A; Shimadzu), and an in-line degasser (CTO-10AS; Shimadzu). The essential oil constituents were separated on a $3-\mu$, reversed-phase, 4.6 $\times 150 \mathrm{~mm}$ analytical chromatography column (HyperClone ODS [C18]; Phenomenex, Torrance, CA), at a 1- $\mu$ injection volume, with an acetonitrile:water gradient (from 50:50 to 90:10 in $20 \mathrm{~min}$ ), and at a flow rate of $0.8 \mathrm{ml} / \mathrm{min}$.

Samples of each oil at known concentrations were analyzed in triplicate using HPLC to verify the reproducibility of the method. The concentrations of thymol, carvacrol, and $p$-cymene were quantified with an external standard method; calibration curves were built as described by Ciola (1998), from the arithmetic mean of the corresponding peak areas of metabolites and their concentrations under the conditions described above. The solvents used for the chromatographic analysis were HPLC grade; absorbance reads were obtained at $202 \mathrm{~nm}$ (for thymol and carvacrol) or $211 \mathrm{~nm}$ (for $p$-cymene).

The experimental delineation was a randomized block design, with four blocks and five treatments. The experimental plot consisted of nine vessels, each containing an established plant. Six plants were randomly selected to assess growth ( 3 plants on day 20 and 3 plants on day 40). The three remaining plants were used in evaluating the other variables studied. Data were compared by Tukey's test at a $5 \%$ probability.

\section{Results and discussion}

Among the Lippia gracilis plants evaluated, the RGR values decreased markedly in parallel with increasing salinity. A growth rate reduction of approximately $30 \%$ was observed in plants exposed to the highest concentration of $\mathrm{NaCl}$ ( 100 $\mathrm{mM}$ ), the RGR was approximately $30 \%$ lower than that observed for the control plants. The RGR was not affected in plants exposed to the lowest concentration of $\mathrm{NaCl}$ ( 25 $\mathrm{mM}$ ), although decreases in the RGR were observed at the higher concentrations (Tab. 1). Similar results were obtained by Hendawy \& Khalid (2005), who reported a $34-48 \%$ reduction in the dry weight of Salvia officinalis exposed to $50 \mathrm{mM}$ of $\mathrm{NaCl}$. In that same species, Taarit et al. (2010) observed a more dramatic (61\%) decrease in plants exposed to $100 \mathrm{mM}$ of $\mathrm{NaCl}$. According to Sudério et al. (2011), salinity affects plant growth by impeding cell elongation, a process mediated by alpha- and beta-galactosidases. Those authors demonstrated that high salinity levels reduce the activity of these enzymes, resulting in delayed stem growth in Vigna unguiculata seedlings.

Salt stress also inhibits plant growth by reducing the osmotic potential in the soil solution. A reduction in osmotic
Table 1. Relative growth rate in Lippia gracilis between 20 and 40 days of exposure to salt stress.

\begin{tabular}{cc}
\hline NaCl concentration & $\begin{array}{c}\text { Mean RGR } \\
\left({\left.\mathrm{g} . \mathrm{g}^{-1} \text { day }^{-1}\right)}^{2}\right.\end{array}$ \\
\hline $0 \mathrm{mM}$ & $1.82 \mathrm{a}$ \\
$25 \mathrm{mM}$ & $1.67 \mathrm{ab}$ \\
$50 \mathrm{mM}$ & $1.63 \mathrm{~b}$ \\
$75 \mathrm{mM}$ & $1.49 \mathrm{bc}$ \\
$100 \mathrm{mM}$ & $1.32 \mathrm{c}$ \\
\hline
\end{tabular}

RGR - relative growth rate.

Means followed by different letters differ significantly ( $p \leq 0.05)$, according to Tukey's test.

potential restricts water availability or causes excessive ion accumulation in plant tissues, resulting in ion toxicity, nutritional imbalance, or both (Tester \& Davenport 2003). Consequently, photosynthetic efficiency is compromised, because salt stress induces stomatal closure to prevent "sweating", thereby limiting the absorption of $\mathrm{CO}_{2}$ (Taarit et al. 2010).

The energy required for osmoregulation is another factor that accounts for reduced growth in plants exposed to high levels of salinity (Gheyi et al. 2005). In the present study, increased concentrations of proline, which plays a role in osmoregulation, were observed in plants under salt stress. At 20 days of exposure, the mean proline concentration was significantly higher than that observed in the control plants only in the plants exposed to $\geq 75 \mathrm{mM}$ of $\mathrm{NaCl}$. However, at 40 days of exposure, the plants exposed to $\geq 25 \mathrm{mM}$ of $\mathrm{NaCl}$ showed proline concentrations that were significantly higher than that observed in control plants. This indicates that exposure time influenced osmoregulation by increasing the production of proline (Tab. 2). In plants, the osmoregulation process involves the synthesis and distribution (in various organs and within the cells) of organic solutes, for the protection of macromolecules, maintenance of membrane integrity, and regulation of ion transport (Willadino \& Camara 2004; Willadino et al. 2011).

Evaluating the dry weight of shoots and roots separately, we found that higher $\mathrm{NaCl}$ concentrations and longer exposure to salt stress translated to lower dry weight values in both (Fig. 1). Linear growth and biomass accumulation in vegetative organs depend on the intensity of cell division and differentiation, both of which are affected by salinity (González 2001). Our results showed that exposure to salt stress for 20 and 40 days affected the growth of roots more than that of the shoots (Fig. 1). Although limited space for root development might have contributed to this result, other authors have reported that root systems are less affected by salinity than are shoots, despite the fact that the roots receive greater exposure to the saline environment (Cavalcanti et al. 2005; Silva et al. 2011).

The RWC did not differ statistically among the treatments evaluated here. The RWC varied from $60 \%$ to $68 \%$ and from $66 \%$ to $73 \%$ at 20 and 40 days of exposure, respectively, indicating that water absorption capacity was not 
Table 2. Proline concentration in leaves of Lippia gracilis after 20 and 40 days of exposure to salt stress.

\begin{tabular}{ccc}
\hline & \multicolumn{2}{c}{ Proline concentration } \\
\cline { 2 - 3 } NaCl concentration & \multicolumn{2}{c}{$(\mathrm{mM} / \mathrm{g}$ fresh weight $)$} \\
\cline { 2 - 3 } & Day 20 & Day 40 \\
\hline $0 \mathrm{mM}$ & $1.03 \mathrm{a}$ & $1.68 \mathrm{a}$ \\
$25 \mathrm{mM}$ & $0.90 \mathrm{a}$ & $5.55 \mathrm{~b}$ \\
$50 \mathrm{mM}$ & $1.97 \mathrm{a}$ & $5.95 \mathrm{~b}$ \\
$75 \mathrm{mM}$ & $4.26 \mathrm{~b}$ & $6.54 \mathrm{~b}$ \\
$100 \mathrm{mM}$ & $4.17 \mathrm{~b}$ & $7.56 \mathrm{~b}$ \\
\hline
\end{tabular}

Means followed by different letters differ significantly ( $p \leq 0.05)$, according to Tukey's test.

affected by the intensity of the salt stress. It is quite likely that the stability of the RWC reflects the accumulation of proline in leaves (Tab. 2), which allowed osmoregulation and the maintenance of hydration. Távora et al. (2001) obtained contrasting results, reporting a decrease in RWC in guava plants exposed to increasing concentrations of $\mathrm{NaCl}$. The authors observed no significant difference in the RWC values in relation to the length of exposure, which was probably attributable to the adaptation of the studied species to water scarcity. Fumis \& Pedras (2002) studied the effects of water stress on wheat cultivars and found that, between two wheat cultivars that maintained constant RWC values, proline concentrations were higher in the cultivar that was more tolerant to water stress. The maintenance of high RWC values might indicate better adaptation to water deficit through greater osmoregulation (Fumis \& Pedras 2002; Maia et al. 2007).

In the present study, we found that salt stress reduced RGR, from $1.23 \%$ in the control plants to $1.07 \%$ in the plants exposed to $100 \mathrm{mM}$ of $\mathrm{NaCl}$. However, the yields of essential oil were not altered by exposure to any concentration of $\mathrm{NaCl}$. Nevertheless, other authors have reported that water stress and salt stress, as well as other stressors, promote increased yields of essential oils (Nerfatti \& Marzouk 2008; Gobbo-Neto \& Lopes 2007). Conversely, Ansari et al. (1998) found that salt stress reduced the yields of essential oils in three species of Cymbopogon.

According to Combrinck et al. (2007), the distribution and structure of trichomes in a plant contribute to controlling transpiration and regulating the temperature of the organ on which they are located. In addition, it has been postulated that trichome density and phenolic compounds produced in these structures provide protection against ultraviolet- $B$ radiation and other abiotic stresses. Although the number of trichomes was not quantified in the present study, this might explain why the plants exposed to salt stress showed essential oil yields similar to those of the plants under no stress, despite the lower RGR observed for the former.

Our analysis of the composition of the essential oils of Lippia gracilis showed that, in the control plants, the principal constituent was carvacrol (at $42.07 \%$ ), followed by thymol (at $32.35 \%$ ), and $p$-cymene (at $17.12 \%$ ). These results are in agreement with those obtained by Albuquerque et al. (2012) in plants of the same species.

In the present study, the concentration of $\mathrm{NaCl}$ did not influence the concentrations of the major components of the essential oil. Other factors, such as the method of extraction and the environmental conditions under which the plants are cultivated, can influence the concentrations of chemical compounds in plants exposed to salt stress. According to Neffati \& Marzouk (2008), the concentrations of chemical compounds in plants can decrease in response to higher levels of salinity. The authors found that the major components of the essential oil of Coriandrum sativum increased at low concentrations of $\mathrm{NaCl}$ and decreased when the concentration was increased to $75 \mathrm{mM}$. In contrast, Taarit et al. (2010) reported that exposure to $25-75 \mathrm{mM}$ of $\mathrm{NaCl}$ increased the yield of sage oil in Salvia officinalis. Increased concentrations of essential oils have also been observed in plants exposed to high temperatures (Morais 2009).
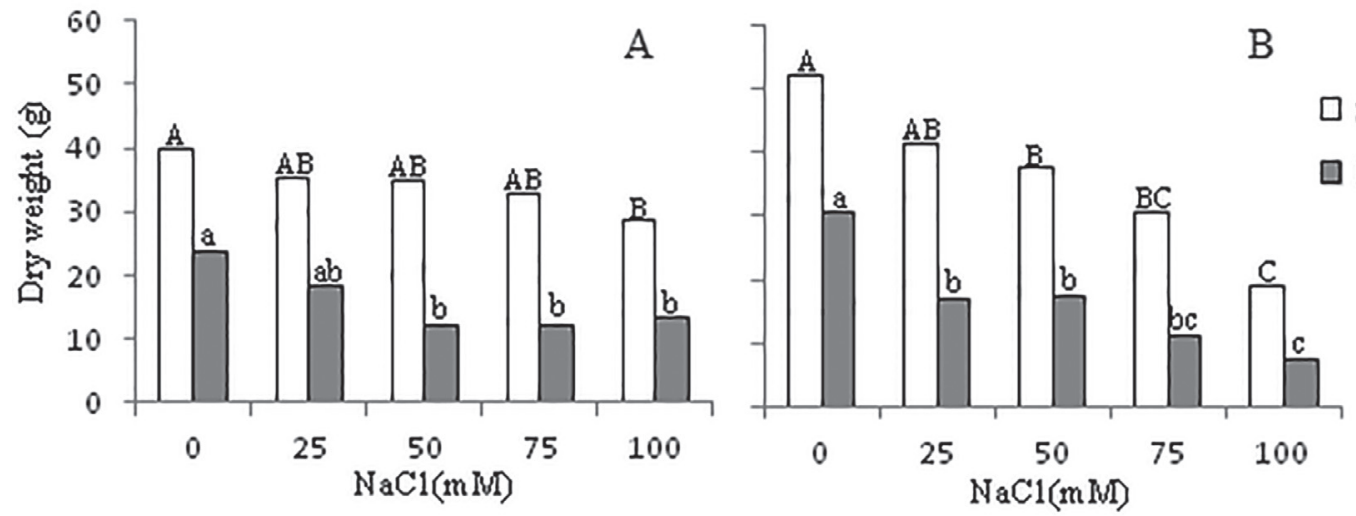

Figure 1. Dry weights of shoots and roots of Lippia gracilis after exposure to various concentrations of $\mathrm{NaCl}$, for 20 days (A) and 40 days (B). Different letters (upper-case over unfilled bars and lower-case over filled bars) indicate significant differences ( $p \leq 0.05)$, according to Tukey's test. 
Our results show that, under the conditions studied, salinity had a negative influence on the growth of Lippia gracilis. That finding might be attributable to the osmoregulation that occurred in the plants, proline concentrations increasing in parallel with increases in the concentration of $\mathrm{NaCl}$.

As previously mentioned, we observed no significant difference in RWC among the treatments evaluated. The highest concentrations of proline in leaves were observed at 40 days of exposure, regardless of the $\mathrm{NaCl}$ concentration. The exposure to salt stress did not affect the yield or the constituent concentrations in the essential oil, carvacrol and thymol showing the highest concentrations in all treatments.

Our results provide information for growing medicinal native plants under conditions of high salinity. It appears that these plants and their active metabolites can be produced at low cost.

\section{Acknowledgments}

This study received financial support from the Brazilian Coordenação de Aperfeiçoamento de Pessoal de Nível Superior (CAPES, Office for the Advancement of Higher Education) and from the Fundação de Apoio à Pesquisa do Estado do Rio Grande do Norte (FAPERN, Foundation for the Support of Research in the State of Rio Grande do Norte).

\section{References}

Albuquerque, C.C.; Camara, T.R.; Mariano, R.L.R.; Willadino, L.; Marcelino Júnior, C. \& Ulisses, C. 2006. Antimicrobial Action of the Essential Oil of Lippia gracilis Schauer. Brazilian Archives of Biology and Technology 49 (4): 527-535.

Albuquerque, C.C.; Camara, T.R.; Santana, A.E.G.; Ulisses, C.; Willadino, L. \& Marcelino Júnior, C. 2012. Effects of the essential oil of Lippia gracilis Schauer on caulinary shoots of heliconia cultivated in vitro. Revista Brasileira de Plantas Medicinais 14 (1): 26-33.

Ansari, S.R., Abad-Farooqi, A.H. \& Sharma, S. 1998. Interspecific variation in sodium and potassium ion accumulation and essential oil metabolism in three Cymbopogon species raised under sodium chloride stress. Journal Essential Oil Research 10 (4): 413-418.

Baser, K.H.C.; Buchbauer, G. 2010. Handbook of essential oils: Science, technology, and applications. Boca Raton/Florida, Taylor and Francis Group.

Carmo Filho, F.; Espínola Sobrinho, J. \& Amorim, A.P. 1987. Dados meteorológicos de Mossoró (janeiro de 1898 a dezembro de 1986). Mossoró: ESAM/FGD. 341: 325p. (Coleção Mossoroense).

Castro, N.E.A.; Carvalho, G.J.; Cardoso, M.G.; Pimentel, F.A.; Correa, R.M. \& Guimarães, L.G.L. 2008. Avaliação de rendimento e dos constituintes químicos do óleo essencial de folhas de Eucalyptus citriodora Hook. colhidas em diferentes épocas do ano em municípios de Minas Gerais. Revista Brasileira de Plantas Medicinais 10 (1): 70-75.

Cavalcanti, M. L. F.; Fernandes, P. D.; Gheyi, H. R.; Barros Júnior, G.; Soares, F.A. L. \& Siqueira, E.C. 2005. Tolerância da mamoneira BRS 149 à salinidade: germinação e características de crescimento. Revista Brasileira de Engenharia Agrícola e Ambiental, Suplemento, p. 57-61.

Ciola, R. 1998. Fundamentos da Cromatografia a Líquido de Alto Desempenho. São Paulo, Edgard Blücher Ltda.
Combrinck, S.; Plooy, G.W.; McCrindle, R.I. \& Botha, B.M. 2007.Morphology and histochemistry of the glandular trichomes of Lippia scaberrima (Verbenaceae). Annals of Botany 99: 111-1119.

Flowers, T.J. 2004. Improving crop salt tolerance. Journal of Experimental Botany 55 (396): 307-319.

Fumis, T.F. \& Pedras, J.F. 2002. Variação nos níveis de prolina, diamina e poliaminas em cultivares de trigo submetidas a déficits hídricos. Pesquisa Agropecuaria Brasileira 37: 449-453.

Gheyi, H.R.; Correia, K.G. \& Fernandes, P.D. 2005. Salinidade do solo e crescimento e desenvolvimento das plantas. Pp. 138-154. In: Nogueira, R.J.M. C.; Araújo, E.L.; Willadino, L.G.; Cavalcante, U.M.T. (eds.). Estresses ambientais: Danos e benefícios em plantas. Recife, UFPE.

Gobbo-Neto, L. \& Lopes, N.P. 2007. Plantas medicinais: fatores de influência no conteúdo de metabólitos secundários. Química Nova 30 (2): 374-381

González, L.M. 2001. Apuntes sobre la fisiologia de lãs plantas cultivadas bajo estrés de salinidad. Cultivo Tropicales 23 (4): 47-57.

Hajimehdipoor, H.; Shekarchi, M.; Khanavi, M.; Adib, N. \& Amri, M. 2010. A validated high performance liquid chromatography method for the analysis of thymol and carvacrol in Thymus vulgaris L. volatile oil. Pharmacognosy Magazine 6 (23): 154-158.

Hendawy, S.F \& Khalid, K.A. 2005. Response of sage (Salvia officinalis L.) plants to zinc application under different salinity levels. Journal of Applied Sciences Research 1: 147-155.

Lima-Júnior, J.A. \& Silva, A.L.P. 2010. Estudo do processo de salinização para indicar medidas de prevenção de solos salinos. Enciclopédia Biosfera 6 (11): 1-21.

Lima, H.R.P.; Kaplan, M.A.C. \& Cruz, A.V. 2003. Influência dos fatores abióticos na produção e variabilidade de terpenóides em plantas. Floresta e Ambiente 10 (2): 71-77.

Maia, P.S.P.; Oliveira Neto, C.F.; Castro, D.S.; Freitas, J.M.N.; Lobato, A.K.S \& Costa, R.C.L. 2007. Conteúdo relativo de água, teor de prolina e carboidratos solúveis totais em folhas de duas cultivares de milho submetidas a estresse hídrico. Revista Brasileira de Biociências 5 (supl. 2): 918-920.

Morais, L.A.S. 2009. Influência dos fatores abióticos na composição química dos óleos essenciais. Horticultura Brasileira 27: 50-63.

Motta-Neto, R.M.; Matos, F.J.A.; Andrade, V.S.; Melo, M.C.N.; Carvalho, C.B.M.; Guimarães, S.B.; Pessoa, O.D.L.; Silva, S.L.; Silva, S.F.R. \& Vasconcelos, P.R.L. 2010. The essential oil from Lippia gracilis Schauer, Verbenaceae, in diabetic rats. Revista Brasileira de Farmacognia 20 (2): 261-266.

Munns, R. 2002. Comparative physiology of salt and water stress. Plant, Cell \& Environment 25: 239-250.

Neffati, M. \& Marzouk, B. 2008. Changes in essential oil and fatty acid composition in coriander (Coriandrum sativum $\mathrm{L}$.) leaves under saline conditions. Industrial Crops and Products 28: 137-142.

Oliveira, O.R.; Terao, D.; Carvalho, A.C.P.P.; Innecco, R. \& Albuquerque, C.C. 2008. Efeito de óleos essenciais de plantas do gênero Lippia sobre fungos contaminantes encontrados na micropropagação de plantas. Revista Ciência Agronômica 39 (1): 94-100.

Sairam, R.K. \& Tyagi, A. 2004. Physiology and molecular biology of salinity stress tolerance in plants. Current Science 86 (3): 407-421.

Silva, E.N.; Ribeiro, R.V.; Ferreira-Silva, S.L.; Viégas, R.A. \& Silveira, J.A.G. 2011. Salt stress induced damages on the photosynthesis of physic nut young plants. Scientia Agricola 68: 62-68.

Silva, F.A.C.; Santos, R.C.; Azevedo Neto, A.; Granja. M.M.C.; Souza, C.C.F. \& Melo Filho, P.A. 2010. Descritores bioquímicos em cultivares de algodoeiro em resposta à inoculação com Colletotrichum gossypii var. cephalosporioides. Tropical Plant Pathology 35 (2): 114-118.

Stanev, S. 2010. Evaluation of the stability and adaptability of the Bulgarian lavender (Lavandula angustifolia Mill.) sorts yield. Agricultural science and Technology 3: 121-123.

Sudério, F.B.; Barbosa, G.K.C.; Gomes-Filho, E. \& Enéas-Filho, J. 2011. O estresse salino retarda o desenvolvimento morfofisiológico e a ativação de galactosidases de parede celular em caules de Vigna unguiculata. Acta Botanica Brasilica 25 (1): 17-24.

Taarit, M.B.; Msaada, K.; Hosni, K. \& Marzouk, B. 2010. Changes in fatty acid and essential oil composition of sage (Salvia officinalis L.) leaves under $\mathrm{NaCl}$ stress. Food Chemistry 119: 951-956. 
Taiz, L. \& Zeiger, E. 2009. Fisiologia vegetal. Porto Alegre, Artmed.

Távora, F.J.A.F.; Ferreira, R.G. \& Hernandez, F.F.F. 2001. Crescimento e relações hídricas em plantas de goiabeira submetidas a estresse salino com NaCl. Revista Brasileira de Fruticultura 23 (2): 441-446.

Tester, M. \& Davenport, R.J. 2003. Na+ tolerance and Na+ transport in higher plants. Annals of Botany 91: 503-527.

Willadino, L. \& Camara, T.R. 2004. Origen y naturaleza de los ambientes salinos. Pp. 303-330. In: Reigosa, M.J.; Pedrol, N. \& Sánchez, A. (eds). La Ecofisiología Vegetal: Una ciencia de síntesis. Madrid, Thomson.

Willadino, L. \& Camara, T.R. 2010. Tolerância das plantas à salinidade: aspectos fisiológicos e bioquímicos. Enciclopédia Biosfera 6 (11): 1-23. Willandino, L., Alves, R.O.F., Arcanjo, E.S.J., Gouveia, A.N. \& Camara, T.R. 2011. Estresse salino em duas variedades de cana-de-açúcar: enzimas do sistema antioxidativo e fluorescência da clorofila. Revista Ciência Agronômica 42 (2): 417-422. 